\title{
Lean Internationalization: How to Globalize Early and Fast in a Small Economy
}

\author{
Michael Neubert
}

\author{
"The journey of a thousand miles starts" \\ from beneath your feet. \\ Lao-Tzu (6th-5th century BC) \\ Philosopher and writer
}

\begin{abstract}
This study examines the early market internationalization of 32 high-tech startups that operate internationally from small and open economies. It uses a comparative cross-national multiple case study research design to explore how such startups may differ in their speed of internationalization. Based on interviews with the founders, the speed of early market internationalization in these startups increases significantly due to the application of lean market development processes. The findings provide a basis for developing propositions for further comparative studies focusing on the early and fast internationalization of high-tech startups based in emerging and developed markets. The study contributes to the literature on networks, internationalization, and international entrepreneurship.
\end{abstract}

\section{Introduction}

Early and fast internationalization of high-tech startups, particularly ones that could be identified as born-global firms (Cavusgil \& Knight, 2015), is a topic that has attracted growing attention in the field of international entrepreneurship, and yet, is among its least researched topics (Neubert, 2015). A born-global firm that internationalizes early and fast is often a high-tech startup with innovative products operating as pioneers in a small global market niche (Neubert, 2015). And, it has a high probability of being located in a small and open economy with a limited home market (Luostarinen \& Gabrielsson, 2006).

A born-global firm from a small and open economy is generally forced to internationalize early and fast to become profitable (Neubert, 2016a). However, early and fast internationalization is very challenging for entrepreneurs because it requires specific abilities and excellent preparation including, for example, product adaptations (Neubert, 2016b). Early and fast internationalization of a born-global firm is considered entrepreneurial and risk-seeking (Oviatt \& McDougall, 2005). It is often associated with high ability, experience, and willingness of the entrepreneur, who might have gone through the first phases of the Uppsala internationaliza- tion process model (Johanson \& Vahlne, 2009) before founding their born-global firm.

This study follows from the author's call for research into the effect of location in a cross-national multiple case study with born-global firms from different small and open economies (Neubert, 2016b). The study asks how and why born-global firms from small and open economies differ in their speed of early market internationalization using Switzerland and Paraguay as a developed and as an emerging economy, respectively.

The article is structured as follows. First, the literature on the classification of high-tech startups and the effect of their country of origin is reviewed. Then, the research methodology of a comparative cross-national multiple case study research design is described. Next, the findings compare the commonalities and differences between the cases. Finally, the article concludes with a list of key findings and recommendations.

\section{Literature Review and Theoretical Framework}

The theoretical framework of this study is based on a review of the literature on the Uppsala internationalization process model (Johanson \& Vahlne, 2009) and born-global firms (Cavusgil \& Knight, 2015). 


\title{
Lean Internationalization: How to Globalize Early and Fast in a Small Economy
}

\author{
Michael Neubert
}

In 1977, Johanson and Vahlne developed the Uppsala internationalization process model (Johanson \& Vahlne, 2009). Their foremost finding was that firms enter new foreign markets using a so-called establishment chain. In the first step of this gradual internationalization process, firms enter geographically and culturally closer markets with low-risk market-entry modes, such as "export", "licensing" or "franchising" in collaboration with a local partner (Neubert, 2016b). With growing international success and market knowledge, they increase their investments, first establishing, for example, a wholly-owned subsidiary, and then they gradually begin to enter more distant foreign markets. Certainly, if market attractiveness decreases, the level of resources dedicated to a foreign market might also decrease, leading to outcomes such as a market exit (Neubert, 2013). According to this logic, Paraguayan firms, for example, should be expected to enter (geographically and culturally closer) foreign markets such as Bolivia and Brazil before they export to the European Union (EU), and Swiss firms should predominately export to neighbouring EU member states such as Germany, Austria, France, or Italy.

Johanson and Vahlne's second finding is related to the liability of foreignness and outsidership. Firms need a firm-specific advantage in every new foreign market in order to compensate for the liability of being a new foreign firm without a client portfolio, a support network to create market opportunities, or sufficient market knowledge. The larger the geographical, administrative, economical, and cultural distance between the home market and the foreign market, the larger the liability of foreignness and outsidership, and the larger the firmspecific advantage needs to be (Johanson \& Vahlne, 2009). Local partners, such as distributors or resellers, help to bridge these differences. The speed of internationalization depends on the speed of learning (Johanson \& Vahlne, 2009) about every new foreign market. This means that the firm must be able to adapt a firmspecific advantage to a sustainable and relevant competitive advantage in every new foreign market to cover the liability of foreignness and outsidership (Johanson \& Vahlne, 2009).

\section{Classification of high-tech startups}

According to Johanson and Vahlne (2009), the Uppsala model can also be applied to firms that begin to internationalize soon after their founding - meaning bornglobal firms (Cavusgil \& Knight, 2015) - because these firms select foreign markets where they can enter quickly and use low-risk and low-cost market-entry modes such as exporting. Both of these actions (selec- tion of market and mode) might be regarded as the first step of the establishment chain of the Uppsala model (Johanson \& Vahlne, 2009).

Most empirical research on early and fast internationalization focuses on high-tech startups in the sense of born-global firms (Servantie et al., 2016). A born-global firm (Cavusgil \& Knight, 2015; Knight \& Liesch, 2016) is a young firm that is active through early export sales. Thus, the born-global concept focuses on a marketseeking internationalization strategy that uses, for example, a global exporter internationalization model (Neubert, 2013). This is the link with the establishment chain of the Uppsala internationalization process model (Johanson \& Vahlne, 2009). Both concepts focus on the market entry mode of "export" as the first step in entering a new foreign market. Further, the word "global" in "born global" should not be understood in the sense that a born-global firm exports immediately to all global markets. Often, the born-global firm starts exporting to a limited number of the most attractive markets or to a particular region such as a free-trade area (Coviello, 2015).

A born-global firm needs to be distinguished from an international new venture. The concept of an international new venture (Oviatt \& McDougall, 2005) analyses all international value chain activities of a young firm including not only exporting but also offshoring, outsourcing, R\&D, production, and sourcing. Thus, the terms born-global firm and international new venture cannot be used synonymously (Coviello, 2015). The high-tech startups analyzed in this article focus (in their current development phase) on market-seeking internationalization activities using the market entry strategy "export" in combination with local distributors to create market opportunities and to acquire clients. Thus, they are classified as born-global firms.

Rasmussen and Tanev (2015) introduced the lean global startup as a new type of firm. In comparison to a born-global firm, a lean global startup is a high-tech startup that creates a new market niche with an innovative technology using a new business model. The internationalization strategy is developed in advance and is part of the initial business plan. Lean global startups implement their business plan using of Blank's (2013) lean startup model. In incremental and iterative product development cycles, lean global startups develop minimum viable products and test them in the market (Blank, 2013). Because of the immediacy of the feedback, products and services can be quickly adapted to market needs. Rasmussen and Tanev (2015) and 


\title{
Lean Internationalization: How to Globalize Early and Fast in a Small Economy
}

\author{
Michael Neubert
}

Tanev and colleagues (2015) make a clear distinction between access to upstream and downstream global resources, both of which must be taken into account when studying lean global startups. The reason for the emphasis on this distinction could be that many hightech startups having a global orientation from their inception may start their global operations through upstream activities (e.g., R\&D and co-innovation with global partners) before they engage into downstream activities (e.g., market development and export). In this sense, lean global startups seem to fit better the definition of international new ventures instead of born-global firms. However, the high-tech startups in this study might also be classified as lean global startups if they were to use a lean startup methodology for their market internationalization.

\section{Effect of location on early and fast internationalization}

The effect of location on early and fast internationalization has gained increasing attention among researchers (Knight \& Liesch, 2016; Hitt et al., 2016), because findings from studies that analyze the fast and early internationalization of high-tech firms from developed economies are not necessarily applicable to emerging economies (Zander et al., 2015). To date, there is little research on born-global from emerging economies (Gonzalez-Perez et al., 2016). A study by Ciravegna, Lopez, and Kundu (2014) emphasizes the importance of social networks - particularly, the networking ability of an entrepreneur as a driver of the speed of internationalization. Hitt, Li, and Xu (2016) and Zucchella, Hagen, Denicolai, and Masucci (2016) reported that the reputation of the home country and the quality of institutions in that country also influence early and fast internationalization.

Small and open economies tend to have a significantly higher rate of born-global firms (Cavusgil \& Knight, 2015) due to the small size of their home market. Therefore, high-tech startups from small and open economies have to internationalize early after their incorporation (Luostarinen \& Gabrielsson, 2006) and will include it in their business plans (Neubert, 2015). Small and open economies have networks of free-trade agreements, which allow high-tech startups to freely move capital, human resources, goods, and services. This aspect is crucial, because high-tech startups need access to resources and clients, which are often not available in their home markets. For the purposes of this study, the two countries of Switzerland and Paraguay are classified as small and open economies.

\section{Research Methodology}

The purpose of this study is to answer the following question: How and why do born-global firms from small and open economies differ in their speed of internationalization? To allow comparisons between developed and emerging countries, cases of high-tech startups were drawn from two small and open economies: Switzerland, representing a developed economy, and Paraguay, representing an emerging economy.

This study uses a comparative cross-national multiple case study research design to answer the explanatory research questions (Yin, 2015). In contrast to an experimental design or a survey, a multiple case study has more flexibility, allows an in-depth analysis of a complex research problem (Yin, 2015) within a highly contextualized environment, and also allows for a comparison between different cases and countries. This research design also allows the use of the replication logic as a way to obtain external and internal validity as well analyzing pattern-matching properties between theories and cases (Yin, 2015).

This study used different sources of evidence to obtain robust conclusions and to achieve construct validity. Therefore, the triangulation concept is applied to the data collection phase to guarantee that different sources of evidence were used to collect data from each case. The primary source for data collection comprised qualitative, semi-structured, in-depth, individual faceto-face interviews with subject-matter experts who were the founders, managers, and shareholders of hightech startups. Other sources of evidence were the corporate websites, product and firm brochures, internal documents provided by the firms, and other secondary data.

The data analysis followed a logical sequence, starting with an individual case analysis, followed by a cross comparison to identify similarities and differences, and finally a literal and theoretical replication using a pattern-matching approach. The goal of this approach is to increase the likelihood of transferring and generalizing the findings to other contexts.

The choice of the sampling strategy is based on the purpose of this study. A random sample from a database of Swiss and Paraguayan high-tech startups was taken until data saturation was achieved after 20 Swiss and 12 Paraguayan interviews. According to Yin (2015), if at 


\title{
Lean Internationalization: How to Globalize Early and Fast in a Small Economy
}

\author{
Michael Neubert
}

least 6 to 10 cases are selected, this sampling strategy produces a statistically representative sample. The interview subjects are all founders, managers, and shareholders of their high-tech startups and mainly hold postgraduate degrees. Evidence of activity in foreign markets was found in $91 \%$ of the sampled high-tech startups.

\section{Findings}

The analysis of the collected data revealed insights into what influences the speed of internationalization of high-tech startups. Primarily, the analysis of the similarities revealed that the Uppsala model might be applied to both countries (Johanson \& Vahlne, 2009; Neubert, 2015). However, although the high-tech startups in each country used an establishment chain, they took different approaches to identify attractive foreign markets. The Paraguayan high-tech startups tended to focus on neighbouring markets, where their liability of foreignness is lower; the Swiss high-tech startups tended to focus on their network, thereby reducing their liability of outsidership. In both cases, the startups focused on developing a firm-specific advantage for local competition and entry into new foreign markets. Indeed, unique, innovative, and high-quality niche market products and local distributors with an existing client network are a precondition for the attractiveness of every new foreign market entry because they compensate for the liability of outsidership and foreignness and ultimately increase the speed of internationalization (Neubert, 2016a).

The second finding is that all the case study firms can indeed be considered born-global firms (Cavusgil \& Knight, 2015; Knight \& Liesch, 2016). These young firms are active through early export sales as their main form of market entry (Coviello, 2015) with strong attention paid to a market-seeking internationalization strategy using, for example, a global exporter internationalization model (Neubert, 2013a). The Swiss high-tech startups can be considered traditional born-global firms seeking market opportunities wherever they are located (Cavusgil \& Knight, 2015). In contrast, the Paraguayan high-tech startups could be classified a "born regionals" (Cavusgil \& Knight, 2015) because they focus on neighbouring markets at the beginning of their internationalization process. Thus, the Uppsala model might be better suited to the Paraguayan high-tech startups, because they select new foreign markets primarily based on the cultural, geographical and economic proximity to their home market, and only to a lesser extent on their attractiveness in the sense of potential for market growth and market size.
Networking and learning ability were identified as the key abilities of the entrepreneurs (Ciravegna et al., 2014; Coviello, 2015; Neubert, 2016b) and the main drivers of the speed of internationalization. Several interviewees mentioned that their whole network has changed since the foundation of their high-tech startups. Thus, they consider the ability to create new contacts in new foreign markets as crucial. Others underlined the qualitative aspect: they believe that the ability to develop business opportunities from their network is even more important with respect to learning with whom you can do business and with whom you cannot. The founders, managers, and shareholders with an educational background in higher education, especially at international institutions, also showed a higher probability and speed of internationalization (Amorós et al., 2016). Networking in the sense of foreign markets is defined as the ability to create market opportunities to acquire new clients and distribution partners with local networks. Thus, the speed of internationalization depends on the ability of a high-tech startup to acquire new clients in foreign markets. Most of the interviewees were involved in foreign business development activities, even though they might have little or no prior experience in international business development, mostly due to their technical background (Neubert, 2016b).

Although all of the interviewees understand the significance of early and fast internationalization (Neubert, 2016a), almost all of the high-tech startups in this study faced significant delays in their internationalization projects even though they have an international strategy and often institutional support (e.g., coaches). Thus, the main challenge lies in the execution, because the business plan is often more a hypothesis (Rasmussen \& Tanev, 2015) than a realistic and proven business model. For example, some of the interviewees complained about their difficulties in finding experienced sales managers with strong international networks and expertise in their small market niche. Even board members often lacked the network to develop realistic business opportunities. Foreign markets are rather selected based on a single business opportunity than the strategic attractiveness of the market. Several parallel foreign market entries lead to an overexpansion of the existing resources without the implementation of efficient market development processes. The founders, managers, and shareholders interviewed in this study generally perceived that this learning experience was necessary to succeed but they admitted that their learning curve might not have been so steep if they had applied tools such as Blank's (2013) lean startup' model or a lean market development process (Neubert, 2013, 


\section{Lean Internationalization: How to Globalize Early and Fast in a Small Economy}

Michael Neubert

2011). Both approaches are supported by the notion that the speed of learning in small, iterative steps defines the speed of early internationalization.

Both, Swiss and Paraguayan high-tech startups understand the importance of early, fast, and lean internationalization. However, they faced significant delays in the execution of their international market-development activities in comparison to the time estimated in their business plans. Most of the interviewees indicated that the reason was a disorganized internationalization behaviour. They are willing and planning to implement efficient and successful foreign market development processes such as the example depicted in Figure 1 (Neubert, 2011, 2013), which shows the degree of structured and disciplined approach that is necessary to manage a global sales organization successfully in contrast to the often creative and unstructured internationalization behaviour of many high-tech startups. As one put it, "the ability to develop new foreign markets should become one of our core competences". Due to this intention, they might be classified as lean global startups (Rasmussen \& Tanev, 2015).

\section{Conclusions}

This study provides some new insights on the factors affecting the speed of internationalization of high-tech startups from emerging and developed small and open economies. It is based on the theoretical framework of the Uppsala model and the born-global firm, and it examines how and why born-global firms differ in their speed of internationalization.
Key findings include:

1. Successful high-tech startups from small and open economies understand the importance of early and fast internationalization.

2. They consider the ability to internationalize successfully and efficiently as one of their core competences.

3. The main tool to execute their internationalization strategy is a lean market development process. As a pioneer in a small global market niche, high-tech startups need to penetrate global markets as fast and as long as they can maintain their competitive advantage.

4. The entrepreneurial team needs the ability to network, to create promising business opportunities, to acquire new business in foreign markets, and to develop a global marketing and sales team, or else their firm will suffer significant delays in their business plans.

In spite of the differences that distinguish both countries of origin, the majority of both Swiss and Paraguayan high-tech startups in this study consider early and fast internationalization important for their enduring survival. The case study firms can be considered as born-global firms, and they follow the establishment chain of the Uppsala model. Thus, one of the contributions of this study is the application of the Uppsala model on high-tech firms from small and open economies that focus on early export.
International Business Development STRATEGY

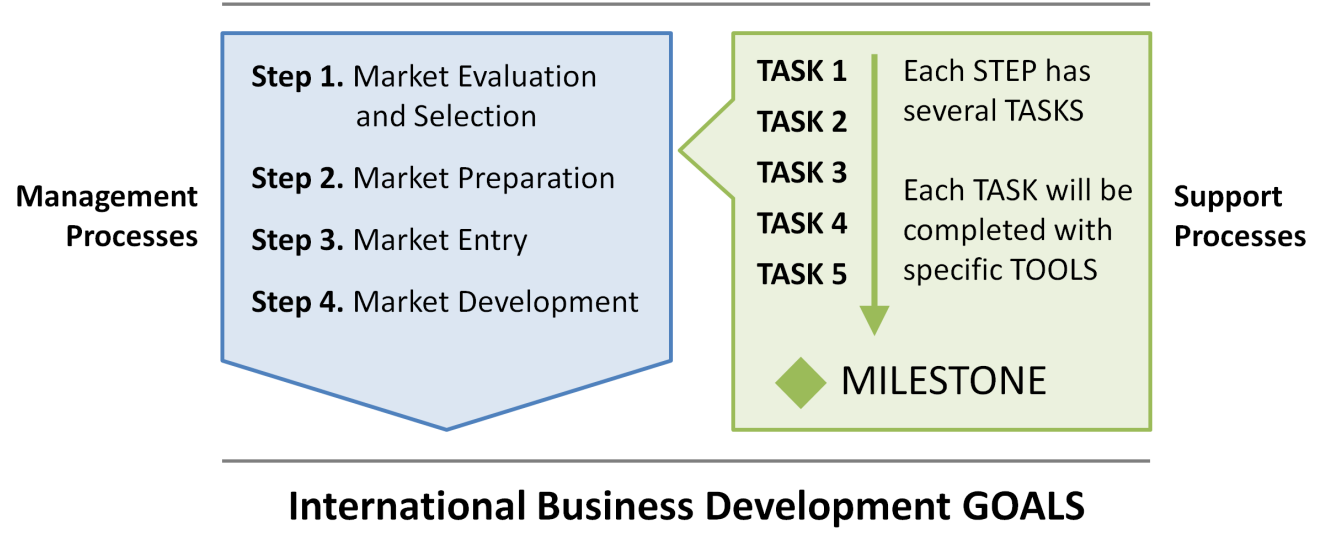

Figure 1. The market development process (Neubert, 2011, 2013) 


\title{
Lean Internationalization: How to Globalize Early and Fast in a Small Economy
}

\author{
Michael Neubert
}

Despite the stated importance of early and fast internationalization, high-tech startups faced significant delays in the execution of their international market-development activities in comparison to the time estimated in their business plans, and this was often due to a disorganized internationalization behaviour. High-tech startups often chase international business opportunities based on their networks or follow existing clients instead of analyzing the attractiveness of foreign markets or following a pre-defined market-development process. Thus, another contribution of this study is that high-tech startups should apply a lean approach to enable an efficient and structured internationalization process. It may help them to close the gap between the aspirations of their strategies and business plans and the hard facts in their balance sheets.

Most of the interviewees understood that this approach reduces the speed of internationalization. They acknowledged the importance of a market-development process that begins with a detailed evaluation and selection of foreign markets before a company actually enters them. Although the Paraguayan high-tech startups initiated their internationalization primarily in neighbouring countries, the Swiss high-tech startups demonstrated a global approach that depends on the attractiveness of each market. All the firms understood that the role and the capabilities of the entrepreneur are crucial for the international success of their high-tech startups. The faster the entrepreneur (Paraguay) and the management team (Switzerland) learn techniques for acquiring clients in foreign markets, the higher the speed of internationalization. Obviously, this includes an intercultural sensitivity to differentiate promising from less promising business opportunities.

The findings of this qualitative multiple case study research project contribute to the research field of international entrepreneurship through better understanding of how and why high-tech startups from small and open economies differ in their speed of internationalization. Furthermore, the findings also add to managerial practice because they will help managers increase the efficiency of international market development. Lastly, policy makers might also benefit from the findings in developing improved public support programmes for high-tech startups.

This comparative cross-national multiple case study research design has several limitations in size and scope that offer new ideas for future research. Future cross-national studies can focus on the differences between other emerging and developed small and open economies.
Future scholarly work might also include quantitative assessments of founder and managerial perceptions combined with qualitative data to provide greater clarification of the statistical significance of the variables of this study. Finally, it would be valuable to include correlational studies to analyze the relationships between variable pairs, for example the networking ability of the entrepreneur and the speed of internationalization.

\section{About the Author}

Michael Neubert is a Professor at the International School of Management in Paris, France, where he obtained his PhD and is now also Chair of the Strategic Management Committee. He is also a Visiting Professor at the Universidad Paraguayo Alemana in Asunción, Paraguay. He teaches international business, strategic management, doing business in foreign markets, and international finance. His research interests concern the internationalization of high-tech startups from small and open economies. Michael is member of the Academy of International Business, and he is a partner of a private equity firm that invests in high-tech startups and supports them in the development of new foreign markets. Michael is also the CEO of C2NM, a Swiss consulting firm specializing in the field of international and intercultural management.

\section{References}

Amorós, J. E., Basco, R., \& Romaní, G. 2016. Determinants of Early Internationalization of New Firms: The Case of Chile. International Entrepreneurship and Management Journal, 12(1): 283-307.

http://dx.doi.org/10.1007/s11365-014-0343-2

Blank, S. 2013. Why the Lean Start-Up Changes Everything. Harvard Business Review, 91(5): 63-72.

Cavusgil, S. T., \& Knight, G. 2015. The Born Global Firm: An Entrepreneurial and Capabilities Perspective on Early and Rapid Internationalization. Journal of International Business Studies, 46(1): 3-16.

http://dx.doi.org/10.1057/jibs.2014.62

Ciravegna, L., Lopez, L., \& Kundu, S. 2014. Country of Origin and Network Effects on Internationalization: A Comparative Study of SMEs from an Emerging and Developed Economy. Journal of Business Research, 67(5): 916-923.

https://doi.org/10.1016/j.jbusres.2013.07.011 


\section{Lean Internationalization: How to Globalize Early and Fast in a Small Economy}

Michael Neubert

Coviello, N. E. 2015. Re-Thinking Research on Born Globals. Journal of International Business Studies, 46(1): 17-26.

http://dx.doi.org/10.1057/jibs.2014.59

Gonzalez-Perez, M. A., Manotas, E. C., \& Ciravegna, L. 2016. International SMEs from Emerging Markets-Insights from the Colombian Textile and Apparel Industry. Journal of International Entrepreneurship, 14(1): 9-31.

http://dx.doi.org/10.1007/s10843-016-0170-3

Hitt, M. A., Li, D., \& Xu, K. 2016. International Strategy: From Local to Global and Beyond. Journal of World Business, 51(1): 58-73. https://doi.org/10.1016/j.jwb.2015.08.016

Johanson, J., \& Valhne, J. E. 2009. The Uppsala Internationalization Process Model Revisited: From Liability of Foreignness to Liability of Outsidership. Journal of International Business Studies, 40(9): 1411-1431.

http://dx.doi.org/10.1057/jibs.2009.24

Luostarinen, R., \& Gabrielsson, M. 2006. Globalisation and Marketing Strategies of Born Globals in SMOPECs. Thunderbird International Business Review, 48(6): 773-801.

http://dx.doi.org/10.1002/tie.20122

Knight, G. A., \& Liesch, P. W. 2016. Internationalization: From Incremental to Born Global. Journal of World Business, 51(1): 93-102.

https://doi.org/10.1016/j.jwb.2015.08.011

Neubert, M. 2011. Internationale Markterschließung: Vier Schritte zum Aufbau neuer Auslandsmärkte. Munich: MI Wirtschaftsbuch.

Neubert, M. 2013. Global Market Strategies: How to Turn Your Company into a Successful International Enterprise. Frankfurt: Campus Verlag.

Neubert, M. 2015. Early Internationalisation of High-Tech Firms: Past Accomplishments and Future Directions. International Journal of Teaching and Case Studies, 6(4): 353-369.

https://doi.org/10.1504/IJTCS.2015.074603

Neubert, M. 2016a. Significance of the Speed of Internationalisation for Born Global Firms - A Multiple Case Study Approach. International Journal of Teaching and Case Studies, 7(1): 66-81. https://doi.org/10.1504/IJTCS.2016.076067
Neubert, M. 2016b. How and Why Born Global Firms Differ in Their Speed of Internationalization - A Multiple Case Study Approach. International Journal of Teaching and Case Studies, 7(2): 118-134. https://doi.org/10.1504/IJTCS.2016.078168

Oparaocha, G. O. 2015. SMEs and International Entrepreneurship: An Institutional Network Perspective. International Business Review, 24(5): 861-873.

https://doi.org/10.1016/j.ibusrev.2015.03.007

Oviatt, B. M., \& McDougall, P. P. 2005. Toward a Theory of International New Ventures. Journal of International Business Studies, 36(1): 29-41.

http://dx.doi.org/10.1057/palgrave.jibs.8490193

Rasmussen, E. S., \& Tanev, S. 2015. The Emergence of the Lean Global Startup as a New Type of Firm. Technology Innovation Management Review, 5(11): 5-12.

https://timreview.ca/article/941

Servantie, V., Cabrol, M., Guieu, G., \& Boissin, J. P. 2016. Is International Entrepreneurship a Field? A Bibliometric Analysis of the Literature (1989-2015). Journal of International Entrepreneurship, 14(2): 168-212. http://dx.doi.org/10.1007/s10843-015-0162-8

Tanev, S., Rasmussen, E. S., Zijdemans, E., Lemminger, R., \& Svendsen, L. L. 2015. Lean and Global Technology Start-Ups: Linking the Two Research Streams. International Journal of Innovation Management, 19(03): 1-41. http://dx.doi.org/10.1142/S1363919615400083

Yin, R. K. 2015. Qualitative Research from Start to Finish. New York: Guilford Publications.

Zander, I., McDougall-Covin, P., \& Rose, E. L. 2015. Born Globals and International Business: Evolution of a Field of Research. Journal of International Business Studies, 46(1): 27-35. http://dx.doi.org/10.1057/jibs.2014.60

Zucchella, A., Hagen, B., Denicolai, S., \& Masucci, M. 2016. Early and Accelerated Internationalisation: The Role of the Niche Strategy in a New Generation of Exporters. International Journal of Export Marketing, 1(1): 27-47. https://doi.org/10.1504/IJEXPORTM.2016.076850 